\title{
Retrospective evaluation of children after stem cell transplantation: Single center experience
}

\section{Kök hücre nakli yapılan hastaların retrospektif olarak değerlendirilmesi: Tek merkez deneyimi}

\author{
Vildan Güngörer, ${ }^{1}$ (1) Ebru Yılmaz Keskin,, 2 [D Tunç Fışgın³ \\ 'Department of Pediatric Rheumatology, Selçuk University Faculty of Medicine, Konya, Turkey \\ ${ }^{2}$ Department of Pediatric Hematology and Oncology, Süleyman Demirel University Faculty of Medicine, Isparta, Turkey \\ ${ }^{3}$ Department of Pediatric Hematology and Oncology, Altınbaş University Faculty of Medicine, İstanbul, Turkey
}

\begin{abstract}
Introduction: Analysis of the data of children following stem cell transplantation.

Methods: A total of 44 children who received stem cell transplant between February 2009 and May 2011 were evaluated retrospectively. Results: Among the patients with a mean age of $9.6 \pm 4.63$ years, 20 (45.5\%) were male, whereas 24 (54.5\%) were female. The initial diagnosis of the patients with decreasing order of frequency was as follows: thalassemia major $(n=15)$, acute leukemia $(n=9)$, Fanconi aplastic anemia $(n=6)$, aplastic anemia $(n=5)$ and other disorders $(n=9)$. Disease-free survival in two years was observed in 27 $(61.3 \%)$ of patients. Relapse occurred in $8(18.1 \%)$ patients, whereas $9(20.4 \%)$ patients died. The mortality was transplant-related in two cases, whereas it was due to progression of the underlying disease in 7 (15.9\%) patients.
\end{abstract}

Discussion and Conclusion: As the stem cell transplantation has become widespread in Türkiye recently, its data are valuable. We found high incidence of mucositis and infection due to myeloablative regimens. The limitation of our study is the small number of patients included. Though, results obtained here are similar to those of national and international studies.

Keywords: Complication; hematopoietic stem cell transplantation; prognosis; transplant-related mortality.

$\mathrm{H}$ ematopoietic stem cell transplantation (HSCT) is a treatment option with a high cure rate for many diseases such as hematologic malignancies, disorders of the immune system and chronic inflammatory diseases. ${ }^{[1]}$

Childhood stem cell recipients are mostly cases with leukemia, hemoglobinopathy, aplastic anemia, lymphoma

\section{Özet}

Amaç: Kök hücre transplantasyonu uygulanan hastaların verilerinin incelenmesi.

Gereç ve Yöntem: Şubat 2009- Mayıs 2011 tarihleri arasında kök hücre transplantasyonu yapılan 44 hasta retrospektif olarak hasta dosyaları ve bilgisayar bilgi sisteminden tarandı.

Bulgular: Hastaların ortalama yaşları 9.6 \pm 4.63 yaş olup, 20 'si (\%45.5) erkek, 24'ü (\%54.5) kızdı. Hastaların sıklık sırasına göre tanıları sıralandığında talasemi major ( $n=15)$, akut lösemi ( $n=9)$, Fankoni aplastic anemisi $(n=6)$, aplastic anemi $(n=5)$ ve diğer hastalıklar $(n=9)$ şeklinde sıralanabilir. Hastaların 27'sinde (\%61.3) 2 yıllık izlemde hastalıksız sağkalım tespit edildi. Sekiz hastada (\%18.1) relaps gelişirken, 9 hasta da (\%20.4) izlem sırasında hayatını kaybetti. Mortalite iki hastada transplant ilişkili iken, 7 hastada (\%15.2) hastalığının ilerlemesi sebebiyle gelişti.

Sonuç: Kök hücre transplantasyonu Türkiye'de yeni yeni yaygınlaşmaya başladığı için çalışmamızın değerli olduğunu düşünüyoruz. Çalışmamızda myeloablatif kemoterapi rejimine bağlı mukozit ve enfeksiyon oranlarını yüksek olarak tespit ettik. Hasta sayımızın az olması çalışmamızın en önemli kısıtlayıcı faktörüydü. Buna ragmen sonuçlarımız ulusal ve uluslar arası çalışmalarla benzerdi.

Anahtar Sözcükler: komplikasyon; kök hücre nakli; prognoz; transplant ilişkili mortalite.

and immune deficiency.

In HSCT patients, the impact of the underlying disease, the conditioning regimens used, antimicrobial prophylaxis and prophylaxis for graft-versus-host disease (GVHD) on the course of treatment, complications, morbidity and mortality are still being investigated. Among the early complications following 
HSCT are GVHD, infections, failure of engraftment, sinusoidal obstruction syndrome (SOS) and hemorrhagic cystitis (HC).

In this study, we aimed to evaluate the characteristics of patients receiving stem cell transplant in our unit. These included their demographic data, dose of transplanted CD34+ stem cells, conditioning regimens used, transplant-related and-unrelated complications, and effect of the management of these complications on transplantation success.

\section{Materials and Method}

This study included all children who received hematopoietic stem cell transplant between February 2009 and May 2011. The study was approved by the Clinical Research Ethics Committee in 2011 (OMU KAEK Resolution No: 2011/746).

All patients and / or their parents were informed about the early and late complications that may occur during transplantation, and an updated consent formula was given.

Relevant data were collected retrospectively from patient files of physicians and nurses, and those saved in computer systems. Demographic data of the patients and their donors, underlying diseases, conditioning regimens used, type of transplantation (allogeneic or autologous), sources of the transplant (bone marrow, peripheral blood or cord blood), doses of stem cells transplanted, time to engraftment, complications and their management, and the prognosis of the patients were all evaluated.

Neutrophil engraftment was defined as the first day of three consecutive days where the absolute neutrophil count (ANC) was 500 cells $/ \mathrm{mm}^{3}$ or greater, whereas platelet engraftment was defined as the finding a platelet count $20.000 / \mathrm{mm}^{3}$ or greater on three consecutive days unsupported by a platelet transfusion. ${ }^{[2]}$

Graft versus host disease was classified as acute or chronic. Cases of GVHD developing within 100 days after HSCT were defined as acute, whereas those occurring after 100 days were defined as chronic. ${ }^{[3]}$

Febrile neutropenia (FN) was defined as suggested in Pediatric FN Guideline. Accordingly, in a patient with an ANC $<500 / \mathrm{mm}^{3}$ or an ANC $500-1.000 / \mathrm{mm}^{3}$, which is however expected to decrease to $<500 / \mathrm{mm}^{3}$ over the next $24-48$ hours, axillary temperature higher than $38.0^{\circ} \mathrm{C}$ at one occasion or higher than $37.5^{\circ} \mathrm{C}$ for at least one hour was considered as $\mathrm{FN}^{[4]}$

Sinusoidal obstruction syndrome was defined according to Modified Seattle Criteria. ${ }^{[5]}$

Hemorrhagic cystitis diagnosis was established on findings of hematuria in clinical and urinary examination.

Polymerase chain reaction (PCR) testing for cytomegalovirus (CMV) was performed twice weekly after HSCT in all the patients. If the CMV PCR titer was found to increase by folding in two consecutive testings or clinical and laboratory findings were indicative of CMV activation, gancyclovir treatment was thought to be indicated.

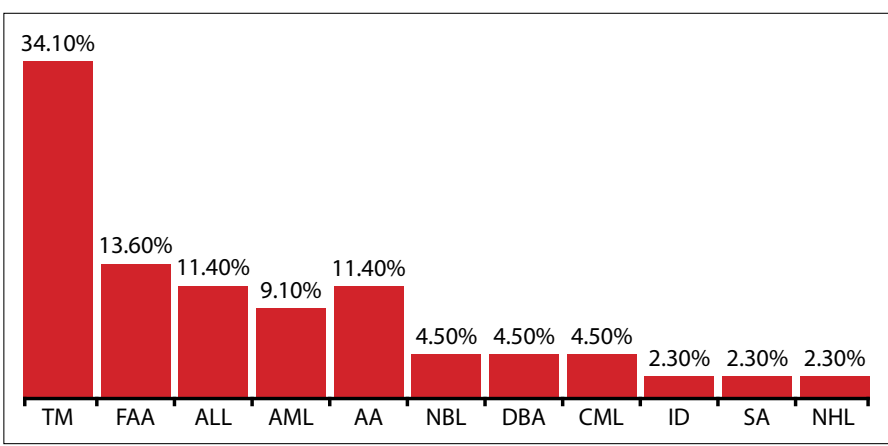

Figure 1. Underlying diseases in study subjects.

TM: Thalassaemia major; FAA: Fanconi aplastic anemia; ALL: Acute lymphoblastic leukemia; AML: Acute myeloid leukemia; AA: Aplastic anemia; NBL: Neuroblastoma; DBA: Diamond-Blackfan anemia; CML: Chronic myeloid leukemia; ID: Immune deficiency; SA: Sideroblastic anemia; NHL: Non-Hodgkin lymphoma.

Death of patients within 100 days after HSCT was considered as transplant-related.

\section{Statistical analysis}

Data were analyzed using Microsoft Excel and SPSS (Statistical Package for Social Sciences) software 15.0 programmes. Numerical variables were given as median, mean and range. For the comparison of categorical variables, Chi-square testing was used. For correlation analyses, Spearman's test, Pearson test and two-proportion testing were used. Mann-Whitney $U$ test was used for the comparison of non-parametric data. A $p$ value $<0.05$ was considered as statistically significant. Survival analysis of the cases was done using Kaplan-Meier survival analysis. For calculation of survival times, the day of stem cell infusion was taken as the beginning, while January the $1^{\text {st }}$, 2013 was taken as the end point.

\section{Results}

\section{Demographic data}

Twenty (45.5\%) of the patients were male, while $24(54.5 \%)$ were female. Their mean age was $9.6 \pm 4.63$ years, ranging from 6 months to 18 years. The underlying diseases in decreasing order of frequency were as follows: TM $(n=15 ; 34.1 \%)$, Fanconi aplastic anemia ( $n=6 ; 13.6 \%)$, aplastic anemia $(n=5 ; 11.4 \%)$, acute lymphoblastic leukemia $(n=5 ; 11.4 \%)$, akut myeloblastic leukemia $(n=4 ; 9.1 \%)$, neuroblastoma $(n=2 ; 4.5 \%)$, chronic myeloid leukemia $(n=2 ; 4.5 \%)$, Diamond-Blackfan anemia $(n=2 ; 4.5 \%)$, severe combined immune deficiency $(n=1 ; 2.3 \%)$, sideroblastic anemia $(n=1 ; 2.3 \%)$ and Non-Hodgkin lymphoma ( $n=1 ; 2.3 \%)$ (Fig. 1).

Forty-one (93.2\%) of the patients received allogeneic transplant, whereas 3 (6.8\%) cases received autologous transplant. The source of transplant was bone marrow, peripheral blood and cord blood+bone marrow in 22 (50\%), 19 (43.2\%) and 3 $(6.8 \%)$ of the cases, respectively.

Doses and types of stem cells infused

The mean dose of $\mathrm{CD} 34+$ +stem cells was calculated as $7.99 \pm 4.61$ 106/kg body weight. The results are shown in detail in Table 1 . 
Table 1. Doses of stem cells infused

\begin{tabular}{lcccc} 
& Minimum & Maximum & Mean & \pm SD \\
\hline Volume $(\mathrm{ml} / \mathrm{kg})$ & 1.8 & 33 & 15.4 & 10.4 \\
$\mathrm{TNC} / \mathrm{kg}\left(10^{8} / \mathrm{kg}\right)$ & 1.83 & 19.8 & 8.6 & 3.8 \\
$\mathrm{MNC} / \mathrm{kg}\left(10^{8} / \mathrm{kg}\right)$ & 0.52 & 9.78 & 2.79 & 2.08 \\
$\mathrm{CD} 34 / \mathrm{kg}\left(10^{6} / \mathrm{kg}\right)$ & 2.09 & 22 & 7.99 & 4.61 \\
\hline
\end{tabular}

TNC: Total nucleated cells; MNC: Mono nuclear cells.

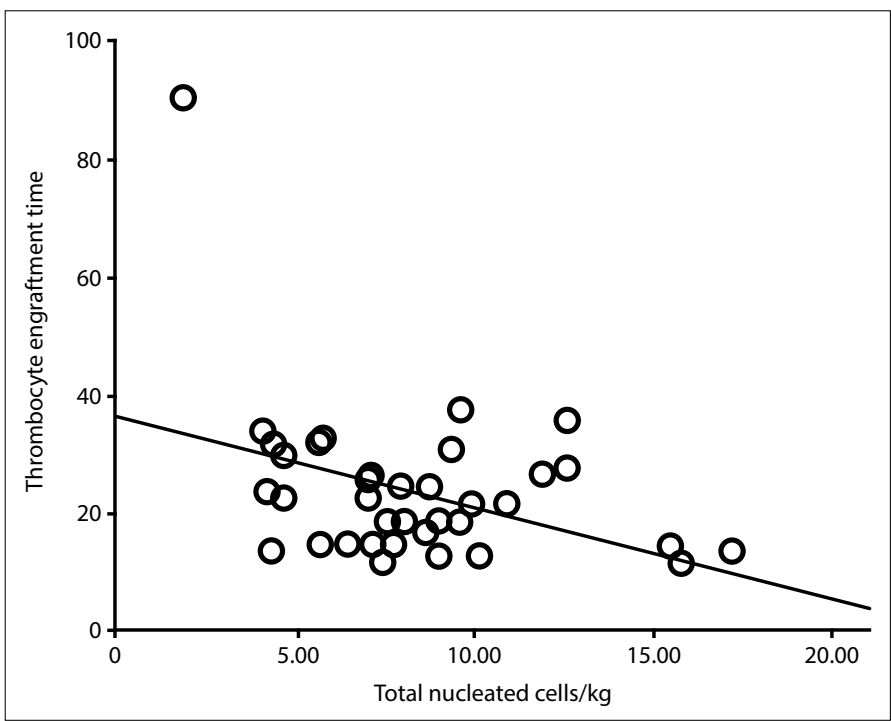

Figure 2. Relationship of total nucleated cells infused (per kg recipient body weight) with thrombocyte engraftment time.

The most commonly used conditioning regimen consisted of busulfan+cyclophosphamide+antithymocyte globulin (ATG).

Time to thrombocyte engraftment showed an inverse correlation with stem cell dose as total nucleated cells (TNC)/kg body weight of the recipient ( $p=0.047$ ) (Fig. 2).

The mean time to neutrophil engraftment was 15.9 days, whereas it was 22.8 days to thrombocyte engraftment.

\section{Complications}

We observed febrile neutropenia as the most common complication. Other complications that developed during the hospitalization in SCTU are presented in Table 2.

Among the cases with $\mathrm{FN}$, the source of fever was detected in $26(61.9 \%)$ subjects, while it was not identified in 16 (38.1\%) cases. Intravascular catheters were the most common ( 16 subjects; $61.5 \%$ ) identified source of infection.

Mucositis developed in 39 (88.6\%) of the cases. All patients with mucositis received total parenteral nutrition (TPN). The mean duration of TPN administration was 15.6 days (range, 0-40 days). In TM patients, duration of TPN administration was shorter than in other cases $(p=0.001)$.

Cytomegalovirus reactivation was noted in 9 (\%20.4) cases, however, none developed CMV disease. The mean time point
Table 2. Complications observed in patients

\begin{tabular}{lcc} 
Complications & Number $(\mathbf{n = 4 4 )}$ & $\mathbf{\%}$ \\
\hline Febrile neutropenia & 42 & 95 \\
Mucositis & 39 & 88.6 \\
CMV activation & 9 & 20.4 \\
GVHD & 6 & 13.6 \\
VOD & 4 & 9 \\
Neurological complication & 3 & 6.8 \\
Hemorrhagic cystitis & 3 & 6.8 \\
Engraftment syndrome & 1 & 2.2 \\
\hline CMV: Cytomegalovirus; GVHD: Graft-versus-host disease; VOD:Veno-occlusive disease.
\end{tabular}

of the beginning of $\mathrm{CMV}$ reactivation was $19.7 \pm 3.01$ days after HSCT.

All of the patients received prophylaxis for GVHD. Graft versus host disease developed in $6(13.6 \%)$ of 44 cases. Patients in whom GVHD developed were given steroids and cyclosporine. Three (6.8\%) patients developed chronic GVHD.

Sinusoidal obstruction syndrome developed in 4 (9\%) patients. All of these patients had TM. Frequency of SOS development was significantly different between TM patients and patients with other diseases $(p=0.020)$, and it was higher in the group receiving hydroxyurea+fludarabine+busulfan $+c y-$ clophosphamide+ATG than in other patients $(p=0.05)$.

Patients receiving cyclophosphamide therapy all received prophylaxis consisting of intense hydration and uromitexan. Though, in 3 (6.8\%) of the patients, HC developed.

All patients received prophylaxis with an anticonvulsant agent. Though, generalized tonic-clonic convulsion occurred in $3(6.8 \%)$ cases. Seizures were kept under control with the use of an additional anticonvulsant agent.

\section{Prognosis}

The mean and median duration of hospitalization in the SCTU were $51.7 \pm 2.28$ days and 24 days, respectively, ranging from 24 to 92 days.

From the 44 patients, 9 deceased. The mortality was transplant-related in two patients (4.5\%), whereas 7 (15.9\%) patients died after 100 days following HSCT due to reasons such as GVHD, infection and progression of the underlying disorder. Relapse occurred in 8 of the cases, whereas disease-free survival was observed in 27 subjects (Fig. 3) (Table 3).

\section{Discussion}

In this study, we evaluated various variables such as the underlying disorders, demographic data, dose of stem cells infused, conditioning regimens used, complications observed and their management, time of neutrophil and thrombocyte engraftment and prognosis in children receiving stem cell transplant.

Taking data on HSCT from the year 2013 into account, the rate 


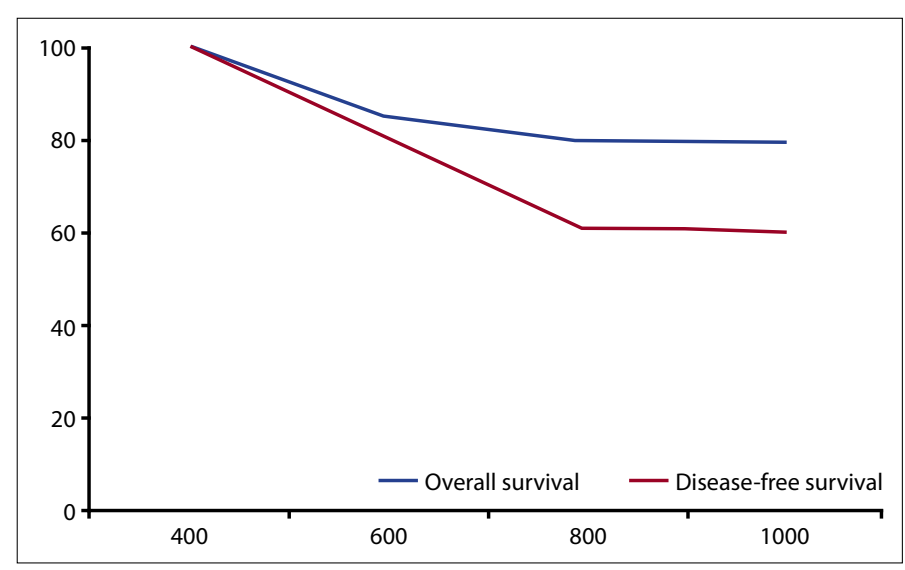

Figure 3. Survival analysis.
Table 3. Prognosis

\section{Prognosis}

Disease-free survival

Relapse

Transplant related death

Death due to other causes

Total

Patient number $(n=44)$

Rate (\%)

61.3

18.1

4.5

15.9

100 of allogeneic HSCT in Turkey is $84.5 \%$, whereas it is $15.5 \%$ for autologous $\mathrm{HSCT}^{[6]}$ In their study including 31.713 children from 450 HSCT centers in Europe, Miano et al. ${ }^{[7]}$ reported in 2008 the rate of allogeneic HSCT to be $59.2 \%$, while that of autologous HSCT was $40.8 \%$. The reason for the low rate (6.8\%) of autologous HSCT in our study can attributed to the facts that our unit is quite new, the majority of patients transplanted had hematologic diseases, and transplantation in oncologic cases was started at a later date.

Since 1986, not only bone marrow, but also peripheral blood has been used with increasing frequency as a source of stem cells with the use of hematopoietic growth factors. ${ }^{[8]}$ On the other hand, cord blood was infused for the first time in 1988 by Gluckman to a child with Fanconi aplastic anemia, and its use in stem cell transplantation has increased since then. ${ }^{\left[{ }^{9]}\right.}$ In the study of Miano et al., ${ }^{[7]} 30 \%$ of allogeneic HSCT cases received peripheral stem cells, while $85 \%$ of autologous HSCT cases received it. In their multicentric study including pediatric HSCT cases, Kansoy et al. ${ }^{[10]}$ reported in 2008 the rates of the use of bone marrow, peripheral stem cells, cord blood and combination of these products as $52.3 \%, 40.8 \%, 2.5 \%$ and $3.6 \%$, respectively. In our unit, $50 \%$ of the cases received bone marrow, $43.2 \%$ peripheral blood and $6.8 \%$ the combination of bone marrow + cord blood. As the low percentage of stem cells in cord blood may cause delay or failure of engraftment, none of our patients was given cord blood solely. Therefore, we think that cord blood should be included among the possible HSCT sources.

The conditioning regimens used before HSCT may help in the long-term management or cure of the disease. However, toxic effects and organ damage caused by the agents included affect the morbidity and mortality. Therefore, complications such as mucositis and FN were observed more commonly.

Engraftment is one of the success criteria in HSCT. We found no difference between allogeneic and autologous HSCT regarding time to engraftment, although the duration to thrombocyte engraftment was shorter with increasing $\mathrm{TNC} / \mathrm{kg}$ body weight. In their study including 40 patients, Goncalves et al. ${ }^{[11]}$ found the median time to neutrophil and thrombocyte engraftments as 19 and 21 days, respectively. In our study, results of engraftment times were in accordance with other studies.

Infectious complications are among the most important causes of transplant-related morbidity and mortality. Beşışık et al. ${ }^{[12]}$ reported the rate of infection before engraftment $60 \%$ in 63 adult cases of allogeneic HSCT. Engels and Kruger reported in 1999 in their study of 104 adult cases of HSCT the infection rates as $55 \%$ and $30 \%$ in allogeneic and autologous HSCT patients, respectively. ${ }^{[13,14]}$ Among our 44 patients, 42 (95.5\%) had FN. Only one of our patients, engraftment syndrome was described, although the rate of this syndrome in allogeneic HSCT cases has been reported as $10-20 \%$ in the literature. ${ }^{[15]}$ Having reviewed our patients, we think that the relatively low number of our cases with engraftment syndrome may point out to the fact that some of our cases considered to have FN with no origin identified may actually have had engraftment syndrome.

Mucositis is one of the important complications in HSCT patients. We could not test blood busulfan levels in our cases, and this may have contributed to the high rate ( $88 \%)$ of mucositis observed. All of our 39 cases with mucositis received TPN. In their single-center study including 92 patients, Sonis et al. ${ }^{[16]}$ reported in 2001 the rates of mucositis $88 \%$ and $83 \%$ in allogeneic and autologous HSCT, respectively. We found significantly shorter TPN use in our patients with TM than other cases $(p=0.001)$. This may be explained by the benign nature of TM which is associated with better nutritional status of these cases compared to patients with malignant diseases who may have cachexia and worse cellular regeneration due to former chemotherapies they received.

Cytomegalovirus causes most often pneumonia and gastrointestinal disease in HSCT patients. Cytomegalovirus reactivation was observed in $20.4 \%$ of our cases, however, none of them developed CMV disease. In their single-center study including 1.418 adult cases of allogeneic HSCT, Gooley et al. ${ }^{[17]}$ reported in 2007 the rate of CMV reactivation as 48\%.

Graft-versus-host disease is among the most important complications of allogeneic HSCT. It is known that the lower the concordance of human leukocyte antigens (HLA) of the recipient and donor is, the more severe is the phenotype of GVHD. ${ }^{[18,19]}$ We observed GVHD in $13.6 \%$ of our patients. Alicia et al. ${ }^{[20]}$ reported in their study including 44 patients the rate of GVHD as 59\%. In their single-center study including 515 cases, Cantoni et al. ${ }^{[21]}$ found that the immunosuppres- 
sive therapy given during GVHD increased the risk of CMV replication. In contrast to other studies, they also reported higher rate of GVHD during CMV replication as a result of increased inflammatory cytokines. None of our patients with CMV reactivation developed GVHD, which is different from the finding of Cantoni et al.

Sinusoidal obstruction syndrome is a life-threatening complication, the severity of which may vary from mild endothelial damage in the liver to hepatic necrosis and cirrhosis. ${ }^{[22]}$ Conditioning regimen we used in TM patients with high risk for hepatotoxicity may have caused disseminated endothelial damage resulting in VOD development, as it involves more chemotherapeutic agents, and they are used for longer duration. Some authors recommend prophylactic use of glutamine to prevent endothelial damage. ${ }^{[23]}$

In their single-center study including 202 pediatric cases, Koh et al. ${ }^{[24]}$ reported that $13.5 \%$ of the patients developed a neurological complication. In our patients, convulsions were the only neurological complications observed, their frequency being $6.8 \%$. We think that the low rate of neurological complications in our patients may be due to the prophylactic use of anticonvulsants (phenytoin or levetiracetam).

The incidence of $\mathrm{HC}$ has been reported as $70 \%$ and $5-35 \%$ in HSCT patients without and with hydration and uromitexan prophylaxis, respectively. ${ }^{[25,26]}$ Yenerel et al. ${ }^{[27]}$ reported the incidence of $\mathrm{HC}$ as $30.4 \%$ in their single-center study including 161 adult cases. The incidence of HC in our cases was quite low (6.8\%). We think that the intense hydration (intravenous fluid of $2500-3000 \mathrm{ml} / \mathrm{m}^{2} /$ day in addition to oral hydration) we started from one day before until $72 \mathrm{~h}$ after cyclophosphamide therapy may have significantly contributed to the low $\mathrm{HC}$ incidence in our cases.

Hematopoietic stem cell transplantation constitutes the only curative treatment option for many diseases. Toxicity in various organs, GVHD and systemic infections may result in morbidity and mortality in some cases. Many studies evaluating the factors affecting the survival have been conducted so far. In the Kaplan-Meier analysis, the rates of survival and disease-free survival were found as $79 \%$ and $61.3 \%$, respectively. GVHD, type of HSCT, time to engraftment, dose of CD34+ cells and FN showed all no correlation with survival (for each of these, $p>0.05$ ). In their study including 31.713 patients from 420 centers, Miano et al. ${ }^{[7]}$ found transplant-related mortality as $11.3 \%$. In the study of Kansoy et al..$^{[10]}$ including 1.067 pediatric cases of HSCT from Turkey, transplant-related mortality was reported as $15 \%$.

\section{Conclusion}

The aim of this study was to make sectional analysis of our HSCT patients transplanted so far. The limitation of our study is the small number of patients included. The number of transplanted cases in our unit is increasing each day, and our results are important in terms of the measures to be taken and studies to be conducted in the future.
Funding: None.

Conflict of interest: There are no relevant conflicts of interest to disclose.

\section{References}

1. Gluckman E, Gratwohl A, Apperley J. The EBMT Handbook. In: J Apperley, E Carreras, E Gluckman, A Gratwohl, T Masszi, editors. Hematopoietic stem cell transplantation for primary amyloidosis in adult ( $5^{\text {th }}$ ed), France 2008 , pp. 424.

2. EBMT criteria, form MED-A 2007.

3. Allen RD, Staley TA, Sidman CL. Differential cytokine expression in acute and chronic murine graft- versus-host-disease. Eur J Immunol 1993; 23(2): 333-37.

4. Ogawa M. Differentiation and Proliferation of Hematopoietic Stem Cells. Blood 1993; 81(11):2844-53.

5. McDonald GB, Hinds MS, Fisher LD, et al. Venoocclusive disease of the liver and multiorgan failure after bone marrow transplantation a cohort study of 355 patients. Ann Intern Med 1993;118(4): 255-67.

6. Kansoy S. TPHD 9. Ulusal Pediatrik Hematoloji Kongresi Van 24-28 mayıs 2013.

7. Miano M, Labopin M, Hartman O, et al. Haematopoietic stem cell transplantation trends in children over the last three decades: a survey by the paediatric diseases woking party of the Europan Group for Blood and Marrow Transplantation. Bone Marrow Transplant 2007; 39: 89-99.

8. Körbling M, Freireich EJ. Twenty five years of peripheral blood stem cell transplantation. Blood. 2011; 117(24): 6411-6.

9. Gluckman E, Broxmeyer HA, Auerbach AD, et al. Hematopoietic reconstitution in a patient with Fanconi's anemia by means of umbilical cord-blood from HLH-identical sibling.N Eng J Med 1989; 321(17):1174-8.

10. Kansoy S. Ulusal Pediatrik HKHT Aktivitesinin Değerlendirilmesi. Ege Üniversitesi Tıp Fakültesi, Pediyatrik KiT Ünitesi, TPHD KiT veritabanı, TPHD KiT Çalışma Grubu. 8. Ulusal Kemik İliği Transplantasyonu Ve Kök Hücre Tedavileri Kongresi 2014.

11. Thissiane L Gonçalves, Dalila M Benvegnú, Gabriela Bonfanti. Specific factors influence the success of autologous and allogeneic hematopoietic stem cell transplantation. Oxid Med Cell Longev 2009; 2(2): 82-87.

12. Beşışık S.K, Ülkemizde akraba dışı allogenik hematopoetik hücre nakli deneyimi. 4. Ulusal Kemik İliği Transplantasyonu ve Kök Hücre Tedavileri Kongresi Bildiri Özetleri, Bursa, 2007 s76.

13. Engels E.A, Ellis C.A, Supran S.E, et al. Early Infection in Bone Marrow Transplantation: Quantitative Study of Clinical Factors That Affect Risk. Clinical Infectious Diseases 1999; 28 (2): 256- 266.

14. Krüger W.H, Boblins J, Kornely O.A, et al. Antimicrobial prophylaxis in allogeneic bone marrow transplantation. Guidelines of the Infectious Diseases Working Party (AGIHO) of the German Society of Haematology and Oncology 2005; 16 (8): 1381-1390.

15. Nobuhiro N, Hiroshi Y, Yoshiyuki T, Asahito H, Hideki M, Makito T, Nao Y, Ayami Y, Kazuko K, Masafumi I, Seiji K. Engraftment syndrome following allogeneic hematopoietic stem cell transplantation in children. Pediatric Transplantation. Pediatric Transplantation 2009; 13(7): 831-837.

16. Stephen T. S, Gerry O, Hank F, Lisa B, Williamson Z.B, John E, Vanessa H, June E, Joel B.E, Francis G.L, Carole M,Douglas E.P, Mark M.S, Frederik K.L, Spijkervet, Mary H. Oral mucositis and the clinical ana economic outcomes of hematopoietic stem cell transplantation. Journal of Clinical Oncology 2001;19(8): 2201-2205. 
17. Ted A. Gooley, Ph.D., Jason W. Chien, M.D., Steven A. Pergam, M.D., M.P.H., Sangeeta Hingorani, M.D., M.P.H., Mohamed L. Sorror, M.D., Michael Boeckh, M.D., Paul J. Martin, M.D., Brenda M. Sandmaier, M.D., Kieren A. Marr, M.D., Frederick R. Appelbaum, M.D., Rainer Storb, M.D., and George B. McDonald, M.D. Reduced Mortality after Allogeneic Hematopoietic-Cell Transplantation. N Engl J Med 2010; 363: 2091-2101.

18. Storb R, Pepe M, Deeg HJ, Anasetti $C$, Appelbaum FR, Bensinger W, Buckner CD, Clift RA, Doney K, Hansen J, Martin P, Pettinger M, Sanders JE, SingerJ, Stewart P, Sulhvan KM, Thomas ED, Witherspoon RP: Long-term follow-up of a controlled trial comparing a combination of methotrexate plus cyclosporine with cyelosporine alone for prophylaxis of graft-versus-host disease in patients administered HLA-identical marrow grafts for leukemia. Blood 1992; 80(2):560.

19. Sullivan KM, Agura E, Anasetti C, et al. Chronic graft-versus-host disease and other late complicarions of bone marrow transplantation. Seminars in Hematology 1991; 28:250.

20. Alicia R, Thomas D, Jörg H, Dominik H, Dimitrios A.T, Martin S, Tuomas W, Jan D.S, Alan T, Alois G, Andre T. Late altered organ function in very long-term survivors after allogeneic hematopoietic stem cell transplantation: a paired comparison with their HLA-identical sibling donor. Hematologica 2010; 96(1):150-155.

21. Cantoni N, Hirsch HH, Khanna N, et al. Evidence for a Bidirectional Relationship between Cytomegalovirus Replication and acute
Graft-versus-Host Disease. Biology of blood and marrow transplantation 2008;16(9): 1309-1314.

22. Cesaro S, Pillon M, Talenti E, et al. A prospective survey on incidence, risk factors and therapy of hepatic veno-occlusive disease in children after hematopoietic stem cell transplantation. Haematologica 2005; 90: 1396-1404.

23. Kuskonmaz B, Yalcin S, Kucukbayrak O, ark. The effect of glutamine supplementation on hematopoietic stem cell transplant outcome in children: a case-control study. Pediatr Transplant 2008;12 (1): 47-51.

24. Koh K.N, Park M, Kim B.E, Im H.J, Seo J.J. Early central nervous system complications after allogeneic hematopoietic stem cell transplantation in children.The Korean Journal of Hematology 2010; 45: 164-70.

25. Leung AY, Mark R, Yuen KY, Cheng VC, Liang V, Kwong YL. Clinicopathological features and risk factors of clinically overt haemorrhagic cystitis complicating bone marrow transplantation. Bone Marrow Transplant 2002; 29(6): 509-13.

26. Seber A, Shu XO, Defor T, Sencer, Ramsay N. Risk Factors for Severe Hemorrhagic Cystitis Following BMT. Bone Marrow Transplant 1999; 23: 35-40.

27. Yenerel M.N, Beşışık S.K, Perdeci O, Gürses N, Tunç M, Sargın D. Hyperbaric oxygen: an important treatment modality in severe hemorrhagic cystitis after allogeneic hematopoietic stem cell transplantation. Turk J Hematol 2009; 26: 176-80. 